352. 炣野 壽, 田村三郎：サフロール誘導体の薬理学的研究 (第 3 報*)

Kotobuki Hano and Saburo Tamura : Pharmacological Studies on Safrole Derivatives. III.

(Pharmacological Department, Osaka Medical College, and Pharmacological Laboratory, Fujisawa Pharmaceutical Industries, Ltd.)

第 2 報に引続いて，小原**等が Table I に示す様な 1- $\beta$-dialkylaminoethoxypheny1-3-methy1-6,7methylenedioxyisoquinoline 6 種を合成したのでその薬理作用に就いて検討した. Table I の化学樍造を通 覧すれば，共通の骨格として 3-methyl-6,7-methylenedioxyisoquinoline を持つているが，との種の化合物 の中には eupaverine や neupaverine の样な平滑筋の鎮座作用を持つたすのがある事は第 1 報て述べた通りて 岕る。

Table I. Six Compounds of 1- $\beta$-Dialkylaminoethoxyphenyl-3-methyl6,7 -methylenedioxyisoquinoline

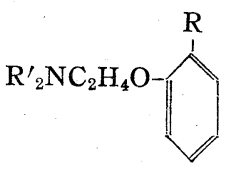

(A)

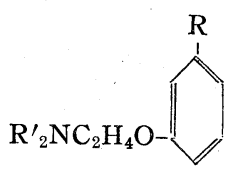

(B)

No. $1 \mathrm{R}^{\prime}=\mathrm{C}_{2} \mathrm{H}_{5}$

No. $2 \mathrm{R}^{\prime}=\mathrm{CH}_{3}$

No. $3 \quad \mathrm{R}^{\prime}=\mathrm{C}_{2} \mathrm{H}_{5}$

No. $4 \quad \mathrm{R}^{\prime}=\mathrm{CH}_{3}$<smiles>[R]c1ccc(OCC)cc1</smiles>

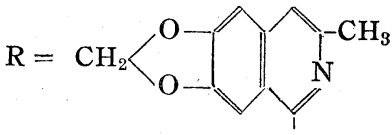

(C) No. $5 \quad \mathrm{R}^{\prime}=\mathrm{C}_{2} \mathrm{H}_{5}$ No. $6 \mathrm{R}^{\prime}=\mathrm{CH}_{3}$

isoquinoline 核の 1 位置换基と鎮病作用との間には有意の関係がある樣であつて, 特に 1 位に phenyl 基の 導入は papaverine 樣の鎮痓作用度増強与るととは既に認められているので, この phenyl 基に alkylaminoethoxy 群を $o-, m-, p-$ の位置に入れた Table I の化合物の中何れが最す作用が強いか䰹味の岀る処で女 る.よつて先ずこれら一連の化合物に就いて平滑筋に対する鎮痓作用の有無をしらべた处何れの化合物も多少そ の作用が認められるが, その中です特に No. 3 㵊も強く, No. 4 これに次ぎ, No. 5, 1, 2, 6 の順序です

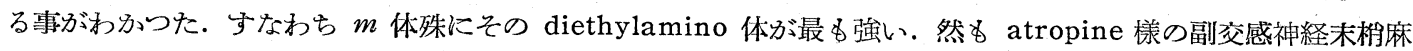

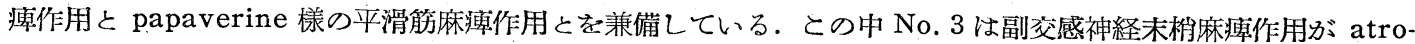
pine に較べると著しく弱いが，平滑筋麻源作用は papaverine とほぼ同等である。 xanthene-9-carboxylate の methobromide は鎮痤作用の強い事は一般に知られているが, Table I の化合 物の methobromide はそれと同樣に, 抗 acetylcholine 作用が原化合物よりる増強すると考穴られるのて， その methobromide に就いて抗 acetylcholine 作用及び抗 pilocarpine 作用をしらべた処, No. 3 の methobromide は最子作用強く, No. 5, No. 4, とれに次ぎ, No. 2 及び No. 1 は弱い. 原化合物とその methobromide の鎮痓作用に於いて摘出腸管実験ではその効力に差を認めないが, 生体実験ては methobromide の方

Table II. Methobromide of No. 3 and Xanthene Compound

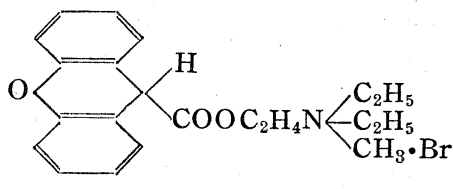

Xanthene compound

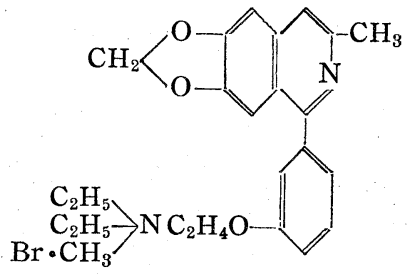

Methobromide of No. 3

* 第 1 報：本誌 72,623(1952)；第 72 回日本薬学会年会講演 (1952).

** Nukii 994, Koganei-cho, Kitatama-gun, Tokyo. 
が強く現われる．とのととは methobromide 体に自律神経遮断作用があるとすれば当然の現象といえよ5。な 特 No. 3 のマウス皮下注射による $\mathrm{LD}_{50}$ は $0.25 \mathrm{mg} / \mathrm{g}$ で岁り その methobromide の $\mathrm{LD}_{50}$ は試料の関係 で正確に測定は出来なかつたが， $0.02 \mathrm{mg} / \mathrm{g}$ 以下て, methobromide 体は原化合物よりも毒性は強く特に呼吸障 碍作用が強い. No. 3 、家鬼に静脈注射すると薬用量で血圧を一過性に下降し, 呼吸を僅に興奮せしめ, 血管を 僅少ながら拡張する. 子棠筋には No. 1 の夕にアミン樣の緊縮作用が認められ，No. 3 及び No. 4 には弱いな がら抗ヒススタミン作用がある。

本研究は文部省科学試験研究費の補助を受けたこと並びに実験に際し種々御便宜を与えられを森 実氏並びに植 田高三博士に深謝し，委た実験に使用しを薬物を合成された小原正郎氏等に厚く御礼を申し上げる。

\section{実験 の: 部}

1. 家鬼摘出腸管に対する作用 第 1 䧼記载の様に Magnus 法によつて，家鬼の摘出小腸管に対する作用を しらべを処, Table I の 6 種の化合物は何れも小腸管の緊張を低下し，その運動を抑制する作用のむるを認め た。その有效最小濃度は Table III の様である。

Table III. Minimum Efficient Concentration on Isolated Small Intestines of Rabbit

Compound
No. 1
No. 2
No. 3
No. 4
No. 5
No. 6
Minimum efficient concentration

$\begin{array}{ll}\text { (1: about } & 200,000) \\ (1: \text { " } & 100,000) \\ (1: \text { " } & 750,000) \\ (1: \text { " } & 200,000) \\ (1: \text { " } & 200,000) \\ (1: \text { " } & 100,000)\end{array}$

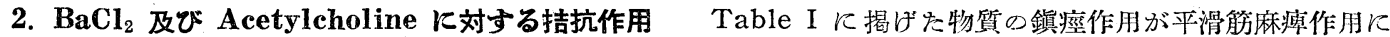
よるものか，或いは副交感神経の末梢を麻疾するものであるかをしらべた。モルモットの摘出腸管に $\mathrm{BaCl}_{2}$ 及び acetylcholine の一定濃度液一䇥舅を作用して，生起する腸管の變縮を緩解する作用の有無及びその効力を各試

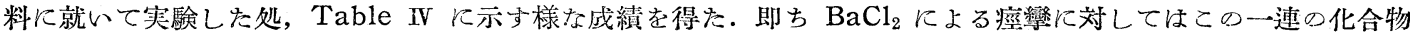
の中で No. 3 は最も鎮痓作用が強く，その効力は papaverine とほぼ等しい。また acetylcholine による症攣

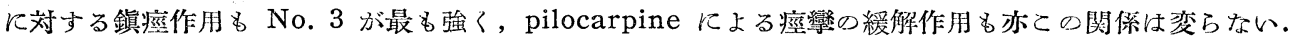

Table IV. Comparative Antispasmodic Effect of Compounds No. 1 to 6

$\begin{array}{cc}\text { Compound } & \begin{array}{c}\text { Anti-BaCl} \\ \text { Minimum efficient } \\ \text { concentration }\end{array} \\ \text { No. } 1 & 25,000 \\ \text { No. } 2 & 50,000 \\ \text { No. } 3 & 500,000 \\ \text { No. } 4 & 100,000 \\ \text { No. } 5 & 100,000 \\ \text { No. } 6 & 50,000 \\ \text { Papaverine } & 500,000\end{array}$

Atropine

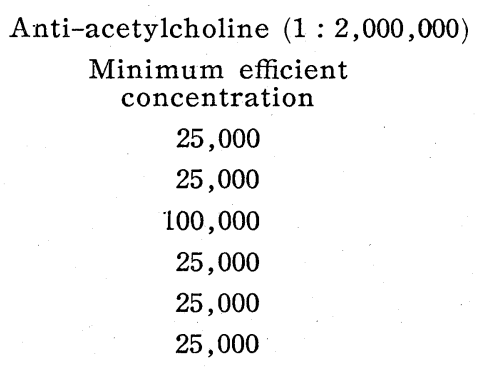

$75,000,000$

3. 生体家鬼腸管に対する作用 摘出实験では比較的効力の強いNo. 3 及び No. 5 に就いて Trendelenburg 法によつて生体家兔腸管に対する作用を papaverine と比較した. No. 3 は $2 \mathrm{mg} / \mathrm{kg}$ の静脈注射で作用 は殆んど現われないが, $3 \mathrm{mg} / \mathrm{kg}$ の静脈注射で顕著に腸管の緊張を低下し，その運動を抑制する。塩酸パパべリ ンに就いて实験した結果もこれと同様でゅる (Fig. 1). No. 5 は $3 \mathrm{mg} / \mathrm{kg}$ の注射では作用が明瞭でないが，5 $\mathrm{mg} / \mathrm{kg}$ では顕著でゅる。

4. Methobromide 体の鎮㾏作用 モルモット摘出腸管を使つて acetylcholine 及び pilocarpine に対す る拮抗作用をしらべた処，Table V の㴍な成績を得た。

これ等 methobromide 中の作用の強いNo. 3,4 及び 5 に就いて, 原化合物と家鬼腸管に対する作用を比 較した処，摘出腸管実験では原化合物とその methobromide との間には効力の差は殆んど認められないが，生 体家鬼の実騟では methobromide の方が強い(Fig. 1 及び Fig. 2). 
Table V. Antagonism of Compounds No. 1 to 6 Methobromide with Acetylcholine and Pilocarpine

\begin{tabular}{|c|c|c|c|c|}
\hline \multirow{2}{*}{ Compound } & \multicolumn{2}{|c|}{$\begin{array}{l}\text { Anti-pilocarpine } \\
(1: 250,000)\end{array}$} & \multicolumn{2}{|c|}{$\begin{array}{l}\text { Anti-acetylcholine } \\
(1: 1,000,000)\end{array}$} \\
\hline & Concentration & Effect & Concentration & Effect \\
\hline No. 1 & $(1: 50,000)$ & - & $\quad(1: 25,000)$ & - \\
\hline No. 2 & II & \pm & " & - \\
\hline No. 3 & " & H & $(1: 500,000)$ & \pm \\
\hline No. 4 & " & + & $(1: 25,000)$ & + \\
\hline No. 5 & "I & + & $(1: 100,000)$ & \pm \\
\hline No. 6 & "y & - & $(1: 25,000)$ & \pm \\
\hline Atropine & i & & $(1: 75,000,000)$ & \pm \\
\hline
\end{tabular}

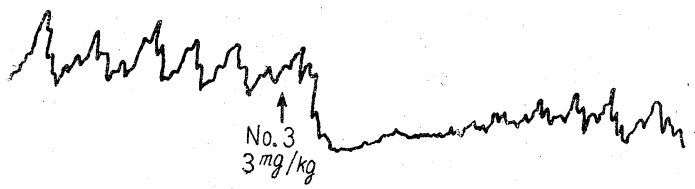

Fig. 1. Comparative Effect of Compounds No.3, its Methobromide and Papaverine on Rabbit Small Intestines in situ (3 mg. $/ \mathrm{kg}$. intravenous injection)
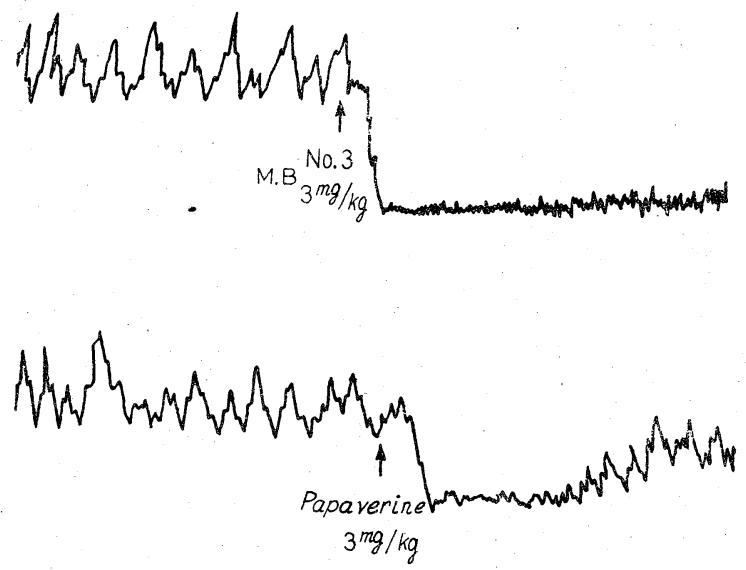
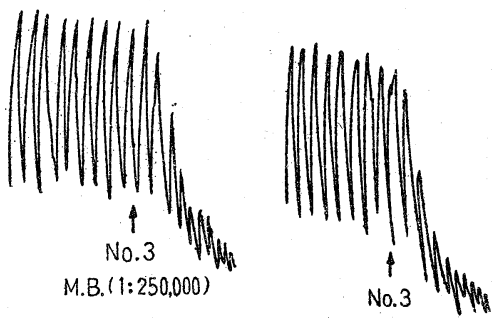

(1:250,000)

Fig. 2. Comparative Inhibitory Effect of Compounds No. 3 and its Methobromide on Isolated Small Intestinal Tonus and Motility of Rabbit at $38^{\circ} \mathrm{C}$ (Magnus method)

5. 毒性 鎭㾏作用の強いNo. 4 及びNo. 5 を夫љマウスに皮下注射し, その LD 法によつて求めた処, 炏ぎの結果を得た。
No. $3 \quad \mathrm{LD}_{50}$
$0.25 \mathrm{mg} . / \mathrm{g}$. (Standard error $\pm 0.01 \mathrm{mg} / \mathrm{g}$ )
No. $4 \quad \mathrm{LD}_{50}$. $0.20 \mathrm{mg} . \mathrm{g}$. (Standard error $\pm 0.01 \mathrm{mg} / \mathrm{g}$ )
No. 3 methobromide $\mathrm{LD}_{50}$ about $0.02 \mathrm{mg} . / \mathrm{g}$.

(Note : $1 \%$ solution, subcutaneous injection in mouse)

即ち methobromide の毒性は原化合物よりも強い。中毒壆注射時の一般症状は注射後約 10 分頃から呼吸促

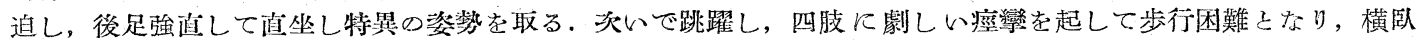
し, 呼吸麻㾇によつて死亡する。

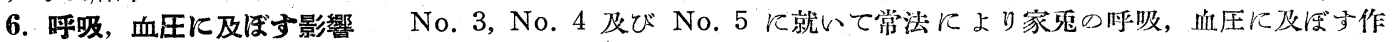
用を実験した処， $1 \mathrm{mg} / \mathrm{kg}$ の静脈注射では血圧を僅かに低下するに過ぎず且つ作用は一過性である。呼吸はこの 際瞬時僅かに抑制やられるが始んど変化なく, $3 \mathrm{mg} / \mathrm{kg}$ では血圧は一過性に下降し, 呼吸は僅かに興巂した後や や抑制せられ，次第に回復する。乙れ等の物質の methobromide に就いて同様に实験し，原化合物こ比較する に呼吸並びに血圧に及ぼす作用は methobromide の方が原化合物よりも強く， methobromide $3 \mathrm{mg} / \mathrm{kg}$ の静 脈注射では血圧が激しく動搖を起した後急激に下降し，この時生起する呼吸障害によつて整死するに至る。

7. 血管に対する作用 蟇を使つて Laewen-Trendelenburg 下肢灌流法によつて实験した結果では灌流液 
のゴム管内に No. 3 の 0.1 1\%溶液 $1 \mathrm{cc}$ を注入するとき血管は僅かに桩張する.

8. 子宮筋に対する作用 モルモットの摘出子宮に就いて Magnus 法で比較すると, No. 1 のはアミン様

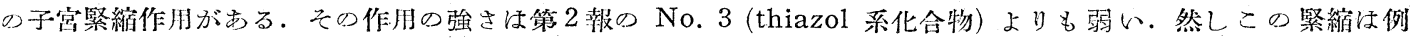
外なく起るものではな?，緊縮した子宮には時として却つて緩解する事がある。

9. 抗ヒスタミン作用 モルモットの摘出腸管に塩酸ヒスタミン及び試料のそれぞれ 50 万倍及び 10 万倍液 起作用山しめ腸管の緊縮が生起するか否かを钼察した処，No. 3, No. 4 及び No. 5 等は総べとスタミンに拮 抗作用を示したが，その效力は diphenhydramine hydrochloride に比較すると極めて弱い。

大阪医科大学薬理学教富 藤沢薬品工業株式会社試験部

\section{Summary}

Antispasmodic action of six kinds of safrole derivatives of isoquinoline series, $1-\beta$-dialkylaminoethoxypheny1-3-methy1-6,7-methylenedioxyisoquinoline, against smooth muscles was examined. A compound possessing a diethylaminoethoxyl group in the meta-position of the 1-phenyl radical had the strongest action and its effect was somewhat similar to papaverine. This compound also possessed paralytic action on peripheral distribution of the parasympathetic nerves, though much weaker than that of atropine, and its toxicity, $\mathrm{LD}_{50}$, was $0.25 \mathrm{mg} . / \mathrm{g}$. by subcutaneous injection in mice. Its methobromide was much stronger than the original compound, possessed a weak antihistaminic action, and its toxicity, $\mathrm{LD}_{\overline{5} 0}$, was about $0.02 \mathrm{mg} . / \mathrm{g}$.

(Received July 20, 1955)

\section{3. 田村三郎：サフロール誘導体の薬理学的研究（第 4 報*)}

Saburo Tamura : Pharmacological Studies on Safrole Derivatives. IV.

(Pharmacological Laboratory, Fujisawa Pharmaceutical Industries, Ltd**.)

前報でフロールから誘導された 3-methy1-6,7-methylendioxyisoquinoline の 1 位に $\beta$-diethylaminoethoxyphenyl 群を持つたもの 3 種の中で $3^{\prime}$ の位置に diethylaminoethoxy 群を持つた物犋 (No. 1) が平 滑筋に詨する鎮痓作用が最も強く，その効力は papaverine とほぼ同程度である事を報告した。 今度藤沢等は No. 1 の 3,4-dihydro 体 (No. 2) を合成されたのて, との化合物についてその薬理作用を No. 1 と比較検討 した. 一般に dihydro 体は原不飽和体よりも効力強く, 毒性は却つて弱い事は知られているが，との原則は総て の物質に当てはめられるものでなく，との両者間ては寧ら不飽和体の方が dihydro 体よりる鎮痓作用は強く， 毒性は殆んぞ差がないよらな結果を得た. また前報で No. 1 の methobromide 体は in vitro では原化合物と その鎮症効力に美を認めないが， in vivo では methobromide 体の方が強い事を述べ, methobromide とする 事によつて神経節遮断作用が現われるのである5と述べたが，とれと化学構造上 1 位に dialkylaminoethoxy 群老持つ点に於いて類似をある 2-methoxy-6-ally1-1-phenoxyethyldiallylamine を例に取ると本化合物は平 滑筋の鎮痤作用は持つていないが，その methiodide (No. 3) は papaverine と汪济同程度の鎮痤作用圶持つ よらになり，また同じく平滑筋である子宮筋に対して No. 3 の原化合物は強い粲縮作用を持つているが)，その methiodide (No. 3) は子宮緊縮作用が殆んど認められない事実から考察すると, methiodide 体は自律神経遮 断作用の女る事が注ぼ確認せられる。即ち三価の案素が四価のアンモニウム塩と成る事によつて自律神経遮断作

* 本稿の一部は第73 回日本薬学会年会講演 $(1953)$.

1) 貫, 小坂, 樋口：実地医家と臨床 17, 1221(1940). 